\title{
Evidence for a basic level in event taxonomies
}

\author{
ANTHONY RIFKIN \\ City University of New York, New York, New York
}

\begin{abstract}
The proposition that event taxonomies have a "basic" level was tested. In the first two tasks of the experiment, taxonomically related event categories were elicited. Nine taxonomies were constructed from subjects' responses on these tasks. In the third task, subjects listed attributes for events categories from the three levels of abstraction of these taxonomies. A single, common level of abstraction (the basic level) was identified. Subjects listed significantly more attributes for basic categories than for superordinate categories, but not significantly more attributes for the lower, subordinate-level categories. Further analyses showed that basic and subordinate categories elicited a greater number of concrete and event-related features than action and personrelated features, and that superordinate categories showed the opposite trend. These findings are discussed in terms of general principles of categorization applied to events, objects, and scenes, and the particular characteristics of events.
\end{abstract}

Research has shown that people organize their knowledge of everyday activities in terms of the generic and stereotypical characteristics of these activities. The typical sequence of actions within activities is commonly agreed upon, and the actions of these events are sequentially organized in memory as "scripts" (Barsalou \& Sewell, 1985; Bower, Black, \& Turner, 1979). Additionally, the actions of events are hierarchically organized. Galambos and Rips (1982) found actions to be hierarchically ordered based on their centrality within activities, and Abbott, Black, and Smith (1985) found a hierarchical structuring of actions in terms of their generality.

The hierarchical organization of actions as "parts" of events indicates that event knowledge is organized in partonomies. It has been suggested that the partonomic organizations of event knowledge have a "basic" level comparable to the taxonomic organizations of object knowledge. Along these lines, Abbott et al. (1985) found a level of abstraction within event partonomies which people prefer to use for describing events. For example, they found that general act descriptions or "scene headers" such as "ordering" a meal, were frequently inferred for a "restaurant" event, while more specific actions, such as "reading a menu" and "discussing what to eat," were less frequently inferred. From this evidence, Abbott et al. suggested that this general level of abstraction may be a "basic" level similar to that found in object taxonomies by Rosch, Mervis, Gray, Johnson, and Boyes-Braem (1976). Rosch (1978) arrived at a similar conclusion when

I am especially grateful to Katherine Nelson, Andrea Blau, and everybody in the Developmental Psychology Program for their support, direction, and criticisms. This research was supported in part by a predoctoral NICHD Training Grant Fellowship, HD 07196-03, and by NSF Grant BNS 79-14006 to Katherine Nelson. Requests for reprints should be addressed to A. Rifkin, Developmental Psychology Program, City University of New York Graduate Center, 33 West 42nd Street, New York, NY 10036. she found that people use a particular level of act description for reporting their previous days' activities. For example, she found that people reported that they "got dressed" rather than "prepared to go out," a more general description, or "put on shoes," a more specific description.

However, Abbott et al. (1985) noted also that object partonomies may have a basic level similar to that found in event partonomies. This basic level could be determined by the "goodness" of an object's parts, based on the parts' perceptual salience and functional significance (Tversky \& Hemenway, 1984). For example, "arms" and "legs" may be basic parts of the "body" because they are perceptually and functionally distinct from other parts of the body. In contrast, basic acts within events may not be perceptually distinct due to their temporal definitions, but they have distinct functional significance (Abbott et al, 1985). For example, "entering" and "ordering" describe basic acts with distinct functions for "going to a restaurant."

As object knowledge is organized taxonomically and partonomically, event knowledge may be similarly organized. For example, "getting dressed" may be a basiclevel event category (as suggested by Rosch, 1978). Although "putting on shoes" has a partonomic relation to "getting dressed," "getting dressed for work," and "getting dressed for school" would be event categories that are taxonomically subordinate to "getting dressed." If taxonomic relations can be identified for event categories, it then would be possible to test for basic-level events using the operational criteria that Rosch et al. (1976) used for studying object categories.

In particular, Rosch et al. (1976) found that basic-level categories are the most inclusive (highest) level within taxonomies at which attributes are taken as common to all or most members of a category. For example, they found that a number of features were listed as common to a basic category, such as "chairs," whereas few if any features were listed as common to a superordinate category one 
level higher, such as "furniture." A number of features also were listed as common to categories subordinate to the basic categories, such as "kitchen chairs." But the number of features attributed to subordinate categories was not significantly greater than the number of features attributed to the basic categories. As such, Rosch et al. (1976) found the basic level to be the highest level of abstraction at which clusters of features are attributed to categories.

The aim of the present research, therefore, was to find evidence for a basic level in event taxonomies. In addition, the specific types of features listed for event categories were examined. Cantor, Mischel, and Schwartz (1982) had found that a greater number of person-related features are listed for event categories than are features describing the events per se. Person-related features included the social roles, actions, and feelings associated with events, and event-related features included the physical aspects, locations, and atmosphere of events. However, all of Cantor et al.'s (1982) superordinate categories matched a "major personality dimension frequently obtained in person-perception studies" (p. 48), such as "a social situation." Also, Cantor et al. (1982) asked subjects to list the characteristics of "being in" a situation rather than to list the characteristics of the events per se. For example, they asked for the characteristics of "being in a social situation" and "being at a party" rather than asking for the characteristics of "a social situation" or "a party." Therefore, it was of interest to see whether more event-related features would be listed for event categories if reference was made only to the events per se, and not to being in the events.

In the first two tasks of the present experiment, event categories were elicited in terms of their taxonomic relations. The first task was modeled after Battig and Montague's (1969) collection of category norms. In this task, subjects listed the instances of superordinate event categories. These instances were assumed to provide the ordinate (basic) level of the taxonomies. In the second task, the most frequently mentioned instances from the first task were given to subjects who were asked for superordinate and subordinate terms for each. This task was used to determine a "taxonomic depth" of three levels of abstraction within the event taxonomies. On the basis of the most frequently produced responses in these first two tasks, nine taxonomies were constructed with three levels each. The third task tested Rosch et al.'s (1976) basic-level hypothesis for these event taxonomies, that is, whether there is a "most inclusive level in taxonomies at which clusters of attributes, believed to be common to the class named, would be listed" (p. 390). Based on the data of this task, basic-level event categories were identified. It was also predicted that more event-related features than person-related features would be listed for these categories, if no explicit reference was made to "being in" these events.

\section{METHOD}

\section{Taxonomic Relations}

All subjects in the first two tasks were students in undergraduate psychology courses at Brooklyn College of the City University of New York. Subjects participated in the experiment for course credit. In the first task (the superordinate task), 27 subjects were given nine superordinate event categories and were asked to list the members of these categories. Appendix A shows the nine superordinates given to each of the subjects. The phrasings for the superordinate stimuli (e.g., "A Type of Meal" and "A Sport") were adopted to follow the phrasing format used by Battig and Montague (1969) for their stimuli. The instructions were similar to those used by Battig and Montague (1969), but included examples of activities and events rather than items and objects (i.e., the example "A Type of Medical Activity" was given, with the possible members of this category being "a check-up," "surgery," "a shot," "a blood test," and "taking X rays"). Subjects were given 90 sec per item. Appendix A shows all of the instances of the superordinates generated two or more times, the frequency with which they were produced, and the number of instances that were listed only once. The responses shown in parentheses in Appendix A are alternative forms of the instances that were commonly mentioned.

In the second task (the taxonomic depth task), a different group of 27 subjects were asked to list superordinate and subordinate categories for ordinate- (basic-) level categories. The basic-level category stimuli in this task were the six most frequently produced instances for each of the superordinates in the superordinate task The only exceptions to this criterion were the use of "furniture shopping " as an instance of "shopping," and of "walking" and "running, " which were used in place of "motorcycle" and "bicycle," because they are types of "transportation" that do not involve a vehicle. Appendix B shows the basic-level terms that were tested in this task

Each of the subjects responded to 24 stimulus items, and each stimulus item was responded to by 12 subjects. Each stimulus set contained the six basic-level categories from four of the nine superordinates. Each subject responded to either a different set of stimuli or a different order of a set. Each stimulus item was printed on a separate page of a testbooklet. "This is a type of what?" was printed to the left of each item for the superordinate responses.

"What are examples of this activity?" was printed to the right of each item for the subordinate responses. Subjects were given the basic category example "surgery," with "medical activity" as an example of a superordinate category to which it belongs, and "heart surgery" and "exploratory surgery" as examples of subordinates of "surgery." Subjects were given 1 min per item. Appendix B shows all the categories generated by 2 or more subjects, the frequency with which these categories were produced, and the number of categories that were listed only once. The responses shown in parentheses in Appendix B are alternative forms of the categories that were mentioned.

\section{Attribute Listings}

Subjects. Subjects were 50 students in undergraduate psychology courses at Brooklyn College of the City University of New York. All subjects received course credit for participating in the experiment. None of the subjects who had taken part in the other tasks participated in this task

Stimuli. The stimuli were 45 event-category terms (see Appen$\operatorname{dix}(\mathrm{C})$. The categories were the nine superordinates, with two basic/ordinate-level categories for each superordinate and one subordinate category for each of the basic categories. The following criteria were used for selecting the stimuli. First, the basic-level categories were among the six most frequently listed instances of the superordinates in the superordinate task, except for "furniture 
shopping" (see Appendix A). Second, the basic-category terms elicited the superordinates in the taxonomic depth task with a frequency equal to or greater than any other superordinate (see Appendix B). However, in the taxonomic depth task, all of the basiclevel categories under the superordinate "housework" elicited another superordinate more frequently. In particular, "cleaning activity" was named more often. Nonetheless, the superordinate "housework" was used in this experiment, because "cleaning activity" did not encompass all of the instances generated for "housework" in the superordinate task (e.g., "cooking" and "ironing"; see Appendix A and B), and instances of "hygienic activities" also were classified as "cleaning activities" (see Appendix B). All of the original superordinates from the superordinate task, therefore, were used as stimuli in the present experiment.

The third criterion for selecting the basic-level stimuli was the number of subordinates generated for them by 2 or more subjects in the taxonomic depth task (see Appendix B). For the basic categories under the superordinate "transportation," the criterion was two or more agreed-upon subordinates. For the basic categories under the other superordinates, the criterion was four or more agreed-upon subordinates. The subordinate-level stimuli for the present experiment then were selected from the agreed-upon subordinates of the basic categories (see Appendix B). The subordinate terms selected were those that labeled events rather than objects (e.g., "quick breakfast" was used as the subordinate under "breakfast" rather than "bacon and eggs").

The phrasings of the basic-level stimuli were those received in the superordinate task. The terminology used for the superordinate and subordinate stimuli were phrasings received for these categories in the taxonomic depth task.

Procedure. The stimuli were divided into five sets of nine items each: one set of superordinate items, two sets of basic-level items, and two sets of subordinate items. For the basic- and subordinatelevel sets, there was one item per set from each of the nine taxonomies. Ten subjects responded to each set. Subjects were run in groups of 2 to 20 . Each item was printed at the top of a page. The nine pages of items were assembled in a different random order for each subject. Subjects were given 2 min per item.

The instructions were printed on the first page of each test booklet. For each event-category term, subjects were asked to list the characteristics common to that activity. For the basic-level items, the examples "basketball" and "camping vacation" were given For "basketball," subjects were given the example responses "drib bling," "running," "throwing," "tall players," "teams," "baskets," and "bleachers," and for "camping vacation," they were given "time off from work (or school)," "planning for it," "tent," "sleeping bags," "campsite," "buying equipment," " "packing equipment," and "traveling." The instructions warned subjects against responding in terms of associations (e.g., "basketball" reminding them of their "brothers"). After the subjects read the instructions, they also were asked not to write narratives (e.g., not to write that "my brother played for the varsity basketball team, and that he was really good," etc.). The subjects who responded to the subordinate and superordinate items received the same instructions. The examples for the subordinate items were "intramural basketball" and "family camping trip." The example for the superordinate items was "vacation." "Sports" was not used as a superordinate example because this item was tested in the study.

Item tally. For each category, only the attributes listed by at least 3 subjects were counted in the final tabulation. This criterion is similar to that used by Rosch et al. (1976). The responses that reached this criterion are shown in Appendix C. The number of features that did not reach this criterion also are shown in Appendix C. It should be noted that the features shown are exactly those that were listed for the categories. For example, while "pancakes" and "bacon" were listed for "breakfast," they were not listed for its subordinate category, "quick breakfast." Therefore, the feature norms in Appendix $C$ do not necessarily depict transitive relations between the taxonomically related categories, as are found in Rosch et al.'s
(1976) "judge amended" norms. That is, all of the features shown for a category (e.g., "breakfast") are not necessarily properties of all the categories under it (e.g., "quick breakfast").

In addition, the attributes that made it to the final tally were classified as objects (such as "books"), persons (such as "family" or "actors"), actions (such as "skating"), physical attributes (such as "noisy" or "dirty"), locations (such as "stadium"), outcomes (such as "touchdowns" or "passing/failing"), personal states (such as "nervous"), time (such as "late"), and abstract states or things (such as "expensive" or "grammar"). The classification of each attribute that reached the final tally is shown in Appendix C. A graduatestudent judge independently coded $40 \%$ of the features using the above classifications without the examples. The judge was given an equal number of features from each of the classifications, except for the abstract and time features, each of which had only 3 . There was an $87.5 \%$ agreement on the classifications of these features.

Along with the attributes listed for the categories, subjects also listed instances of the categories. For example, "football" and "baseball" were listed for "sports," along with the attributes of this category. Also, categories to which the basic and subordinate terms belong were listed for these terms. For example, "crime", was listed for "murder," and "murder" was listed for "homicide."

These responses that are taxonomically related to the category stimuli were classified as follows and tabulated separately. For the superordinate categories, responses were classified as "basic" categories if they were received as instances of the superordinates in the superordinate task (see Appendix A). None of the subordinate categories received in the taxonomic depth task were listed with the attributes of the superordinates. For the basic categories, responses were classified as "superordinate" or "subordinate" if they had been generated as superordinates or subordinates of these basic categories in the taxonomic depth task (see Appendix B). For the subordinate categories, responses were classified as "basic" if the subordinate category had been listed as an instance of that basic category in the taxonomic depth task. Also, for the subordinate categories, responses were classified as "superordinates" or "subordinates" if they had been generated in the taxonomic depth task as superordinates or subordinates of a basic category to which the subordinate term belongs. Appendix $\mathrm{C}$ shows all of the "superordinate," "basic," and "subordinate" taxonomic terms that reached the final tabulation criterion of being listed by at least 3 subjects. Appendix $C$ also shows the number of taxonomic terms that were listed once or twice for the category stimuli.

\section{RESULTS}

Table 1 shows the mean number of attributes reaching the final tabulation at each level of abstraction. The basiclevel hypothesis for this study was that the basic level would be the most inclusive level in taxonomies at which clusters of features are attributed to categories. T tests showed that the ordinate (basic) level was the "basic" level. These categories elicited significantly more attributes than did the superordinate categories $[\mathrm{t}(8)=5.74$, $p<.001]$, and no difference was found between the number of attributes listed for the basic categories and the number listed for the subordinates $[t(8)=.28]$. The increase in the number of attributes between the superordinate and basic levels was significantly greater than the difference between the number of attributes listed for the basic categories and the number listed for the subordinates $[\mathrm{t}(8)=4.53, \mathrm{p}<.01]$. (This basic-level analysis is the same as that performed by Tversky \& Hemenway, 1983).

Similar basic-level differences were found when the taxonomic terms that had been listed with the attributes of 
Table 1

Number of Attributes in Common at Each Level of Abstraction

\begin{tabular}{|c|c|c|c|c|c|c|}
\hline \multirow[b]{3}{*}{ Category } & \multicolumn{6}{|c|}{ Number of Attributes in Common } \\
\hline & \multicolumn{3}{|c|}{ Without Taxonomic Terms } & \multicolumn{3}{|c|}{ With Taxonomic Terms } \\
\hline & Superordinate & Basic Level & Subordinate & Superordinate & Basic Level & Subordinate \\
\hline Meal & 4 & 9.5 & 8 & 6 & 9.5 & 8 \\
\hline Entertainment & 1 & 5.5 & 7.5 & 6 & 9 & 7.5 \\
\hline School Activities & 1 & 6 & 5.5 & 3 & 7 & 5.5 \\
\hline Sports & 3 & 10 & 7.5 & 8 & 10 & 7.5 \\
\hline Hygiene & 3 & 7.5 & 4.5 & 4 & 7.5 & 4.5 \\
\hline Shopping & 2 & 6 & 5 & 3 & 6 & 5 \\
\hline Crime & 1 & 5.5 & 6.5 & 5 & 6.5 & 7 \\
\hline Transportation & $\mathbf{0}$ & 3.5 & 7.5 & 5 & 3.5 & 7.5 \\
\hline Housework & 2 & 5.5 & 5 & 5 & 5.5 & 5 \\
\hline Averages & 1.9 & 6.6 & 6.3 & 5.0 & 7.2 & 6.4 \\
\hline
\end{tabular}

the categories were included in the analyses (e.g., the "basic" category instances listed for the superordinates; see Appendix C). The difference between the superordinate and basic levels was significant $[\mathrm{t}(8)=2.48$, $\mathrm{p}<.05]$, and no difference was found between the basicand subordinate-level categories $[\mathrm{t}(8)=.94]$. The increases between the superordinate and basic levels were significantly greater than the differences between the basic and subordinate levels $[t(8)=2.48, p<.05]$.

The finding of taxonomic (superordinate, basic, and subordinate) terms being generated in the attribute listings for the categories had not been predicted. These taxonomic terms appeared to be given more often for the superordinate categories. $T$ tests were performed to test this difference. Again, there was a significant difference between the superordinate and basic levels $[t(8)=3.65$, $\mathrm{p}<.01]$, but in the opposite direction: the superordinate categories elicited more taxonomic terms. No difference was found between the basic and subordinate levels [t(8) $=1.40]$.

Analyses were then performed on the types of attributes that had been listed for the categories. Table 2 shows the number of different types of attributes that were generated for the categories at the different levels of abstraction.

$\mathrm{T}$ tests were performed to determine whether there were significant differences between the number of attributes

Table 2

Number of Attributes in Classifications at Each Level of Abstraction

\begin{tabular}{lccc}
\hline & \multicolumn{3}{c}{ Number of Attributes } \\
\cline { 2 - 4 } Classifications & Superordinate & Basic Level & Subordinate \\
\hline Event-related & 4 & 55 & 57 \\
$\quad$ Objects & 0 & 8 & 7 \\
Physical Attributes & 1 & 10 & 6 \\
Locations & 0 & 7 & 0 \\
Outcomes & 0 & 1 & 4 \\
Abstract & 0 & 2 & 2 \\
Time & 5 & 83 & 76 \\
Totals & & & \\
Person-related & 3 & 17 & 19 \\
$\quad$ Persons & 4 & 16 & 14 \\
Actions & 5 & 2 & 5 \\
$\quad$ Personal States & 12 & 35 & 38 \\
Totals & & & \\
\hline
\end{tabular}

describing people (persons, actions, and personal states) and those describing the events (objects, physical attributes, locations, outcomes, time, and abstract states or things). For the basic categories, there was a significantly greater number of event-related than person-related features $[t(17)=3.40, p<.01]$. A significantly greater number of event-related than person-related features also was listed for the subordinate categories $[t(17)=3.27$, $p<.01]$. More person-related features than event-related features were listed for the superordinates, but this difference was not significant $[t(8)=1.94]$. In addition, the categories at the different levels of abstraction were compared in terms of whether they received more eventrelated than person-related features. Proportionally more of the basic categories received more event-related features in contrast to the superordinates which elicited a greater or equal number of person-related features $\left[\chi^{2}(1)=6.69, p<.01\right]$. No such difference was found between the basic and subordinate level categories $\left[\chi^{2}(1)=.13\right]$.

\section{DISCUSSION}

The hypothesis was confirmed that there is a basic, highest level of categorization within event taxonomies at which clusters of features are attributed to events. The superordinate categories received few, if any, attributes that are taken as common to their members. In contrast, more features were listed for the basic- and subordinatelevel categories, and no differences were found between these levels. These findings are similar to those found by Rosch et al. (1976) for object categories and by Tversky and Hemenway (1983) for scene categories. The present findings, therefore, suggest that people apply a similar categorization process to events, scenes, and objects for organizing featural information within these domains.

An unexpected finding was that a number of category and instance terms were listed with the attributes of the event categories. For example, "movies" was frequently listed as an instance of "entertainment" in the superordinate task (see Appendix A) and was also listed with the attributes of "entertainment" in the attribute listing task (see Appendix C). Conversely, "entertainment" was listed in the taxonomic depth task as a category to which "movies" 
belong (see Appendix B), and was listed with the attributes of "movies" in the attribute listing task (see Appendix C). The superordinate categories in particular received a greater number of taxonomic terms in their attribute listings, with basic-level "instances" being listed for the superordinate categories. However, a significant difference was still found between the basic- and superordinate-level categories, when the taxonomic terms received with the attributes were included in the attribute analysis. Therefore, the "basic-level" difference between the superordinate- and basic-level event categories was not based on subjects listing taxonomic terms rather than features for the superordinates. Many more basic-category instances could have been listed for the superordinates (see Appendix A) but were not.

Further research will be necessary to find out why taxonomic terms are listed with the attributes for event categories, especially for the superordinate categories. Basic categories may be listed for the superordinates because they are typical exemplars of the superordinates. As evidence of this, the most frequently listed instances of the superordinates (see Appendix A) were the instances most likely to be included in the attribute listings for the superordinates (Appendix C). These typical exemplars may be reported because of the absence of features common to the superordinates.

Differences also were found in the types of information reported for the different levels of event categorization. The basic- and subordinate-level categories elicited more event-related than person-related features (i.e., more features describing objects, physical attributes, locations, outcomes, time, and abstract states). No difference was found between the number of event-related and personrelated features listed for the superordinate categories. However, more of the superordinate level categories had a greater or equal number of person-related features listed for them (i.e., features describing persons, actions, and personal states) in contrast to the basic categories that had elicited more event-related features. No such difference was found between the basic- and subordinate-level categories.

Of particular interest was the large number of objects received as features of the basic and subordinate categories (see Table 3 and Appendix C). Given the large number of objects generated for these categories, the basic-event categories appear to be the highest level of abstraction at which concrete features of events are organized. In contrast, more abstract person-related features are attributed to superordinate-level categories. For example, "competition" and "fun" were used to describe "sports." This difference between the superordinate- and basic-level categories is similar to what Rosch et al. (1976) found for their object categories. More abstract functional features were listed for their object superordinates (e.g., "makes things" for "tools"), and more concrete part descriptions and physical features were listed for their basic- and subordinate-level object categories (e.g., "blade" and "sharp" for "saw"). A single type of taxonomic-feature organization may therefore exist that is applied to both event and object taxonomies, based on the attribution of abstract features at higher levels and more concrete features at and below the basic level.

The finding of more event-related features being produced for basic- and subordinate-event categories is in contrast to Cantor et al.'s (1982) finding of more person-related features being generated for event categories. However, Cantor et al.'s (1982) event categories were based on personality dimensions obtained in person-perception studies. In line with these personality dimensions, the researchers had asked subjects for the characteristics of "being in" a situation (e.g., the characteristics of "being at a party" rather than the characteristics of "a party"). Such a "participatory" perspective toward events may quite naturally elicit person-related features such as the feelings and actions of people within events. Further research will be necessary to determine how event-related and person-related features are organized within event categories. For example, the objects listed for event categories may be "slotfillers" related to particular actions within the scripts for these events, such as the different types of food that one eats for breakfast (Nelson \& Gruendel, 1981). Or, these objects may be the "parts" of scenes (Tversky \& Hemenway, 1983) that the events are related to. For example, the objects listed for "food shopping" may be those encountered in a "grocery store."

In conclusion, it was found that people taxonomically organize their knowledge of events, and that this organization is similar to that found in other domains. The taxonomic organization of event knowledge may serve specific purposes in the retrieval of event information (Schank, 1982), such as the retrieval of autobiographical memories (Reiser, Black, \& Abelson, 1985). It should be noted, however, that the event taxonomies found here may not be as stable as the object taxonomies studied by Rosch et al. (1976). As can be seen in the results of the taxonomic depth task (Appendix B), many of the agreedupon subordinate categories were generated by only 2 out of 12 subjects. In addition, a single most dominant superordinate was not always produced for the basic-level categories. Event taxonomies may not be as stable as object taxonomies because of the other types of organizational principles, such as partonomic and script organizations, which play strong roles in the organization of event knowledge (Abbott et al., 1985; Barsalou \& Sewell, 1985). As such, event knowledge may be organized in a number of different ways. But, as indicated in the present study, one of these ways is taxonomic.

\section{REFERENCES}

Aвbott, V., Black, J. B., \& Smith, E. E. (1985). The representation of scripts in memory. Journal of Memory \& Language. 24, 179-199. Barsalou, L. W., \& Sewell, D. R. (1985). Contrasting the representation of scripts and categories. Journal of Memory \& Language, 24, 646-665.

Battig, W. F., \& Montague, W. E. (1969). Category norms for ver- 
bal items in 56 categories: A replication and extension of the Connecticut category norms. Journal of Experimental Psychology Monographs, 80(3, Pt. 2).

Bower, G. H., Black, J. B., \& TuRner, T. J. (1979). Scripts in memory for text. Cognitive Psychology, 11, 177-220.

Cantor, N., Mischel, W., \& SChwartz, J. C. (1982). A prototype analysis of psychological situations. Cognitive Psychology, 14, 45-77.

Galambos, J. A., \& Rips, L. J. (1982). Memory for routines. Journal of Verbal Learning \& Verbal Behavior, 21, 260-281.

Nelson, K., \& Gruendel, J. (1981). Generalized event representations: Basic building blocks of cognitive development. In A. Brown \& M. Lamb (Eds.), Advances in developmental psychology (Vol. 1). Hillsdale, NJ: Erlbaum.

Reiser, B. D., Black, J. B. \& Abelson, R. P. (1985). Knowledge structures in the organization and retrieval of autobiographical memories. Cognitive Psychology, 17, 89-137.

Rosch, E. (1978). Principles of categorization. In E. Rosch \& B. B. Lloyd (Eds.), Cognition and categorization. Hillsdale, NJ: Erlbaum. Rosch, E., Mervis, C. B., Gray, W. D., Johnson, D. M., \& BoyesBraem, P. (1976). Basic objects in natural categories. Cognitive Psychology, 8, 382-439

Schank, R. C. (1982). Dynamic memory: A theory of reminding and learning in computers and people. New York: Cambridge University Press.

TVERSKy, B., \& Hemenway, K. (1983). Categories of environmental scenes. Cognitive Psychology, 15, 121-149.

TVERSK, B., \& HEMENWAY, K. (1984). Objects, parts and categories. Journal of Experimental Psychology: General, 113, 169-193.

\section{Instances Listed for Superordinates and Their Production Frequency*}

\begin{tabular}{|c|c|c|c|}
\hline Instances & Frequency & Instances & Frequency \\
\hline \multicolumn{4}{|c|}{ A TYPE OF MEAL } \\
\hline Breakfast & 16 & Vegetables & 3 \\
\hline Lunch & 16 & Rice & 3 \\
\hline Dinner & 16 & Luncheon & 2 \\
\hline Supper & 12 & Bacon \& Eggs & 2 \\
\hline Snack & 10 & Soup & 2 \\
\hline Brunch & 5 & Salad & 2 \\
\hline Fish & 4 & Meat & 2 \\
\hline Dessert & 3 & Potatoes & 2 \\
\hline Sandwich & 3 & Preparation & 2 \\
\hline Hamburgers & 3 & Conversation & 2 \\
\hline Steak & 3 & Instances listed & \\
\hline Chicken & 3 & once & 48 \\
\hline \multicolumn{4}{|c|}{ A TYPE OF ENTERTAINMENT } \\
\hline Movies (Seeing a movie) & 19 & Cardplaying (Cards) & 4 \\
\hline Television (TV, TV show) & 13 & Concerts & 3 \\
\hline Dancing & 10 & Records (Playing records) & 3 \\
\hline Theatre & 7 & Playing a musical instrument & 3 \\
\hline A party (Parties) & 7 & Conversation (Talking) & 3 \\
\hline A play & 7 & Baseball (Baseball game) & 3 \\
\hline Reading & 6 & Tennis & 2 \\
\hline Radio (Listening to radio) & 6 & Football & 2 \\
\hline Sports (Sports event) & 5 & A dance & 2 \\
\hline Music & 5 & Amusement parks & 2 \\
\hline Circus (Circus show) & 5 & Book reading & 2 \\
\hline Games (Playing a game) & 4 & Magazines & 2 \\
\hline Singing & 4 & Drinking & 2 \\
\hline & & Instances listed once & 42 \\
\hline \multicolumn{4}{|c|}{ A GENERAL SCHOOL ACTIVITY } \\
\hline Studying & 12 & Memorizing & 3 \\
\hline Classes (Attending classes, & 10 & Answering questions & 3 \\
\hline Being in classroom) & & Attendance (Taking attendance) & 3 \\
\hline Writing & 9 & Going to library & 3 \\
\hline Taking tests (Tests) & 8 & Carrying school books & 3 \\
\hline Reading & 8 & Being with friends & 3 \\
\hline Doing homework (Homework) & 7 & (Talking with friends) & \\
\hline Observing (Watching, & 7 & Gym & 3 \\
\hline Paying attention) & & Socializing & 2 \\
\hline Taking notes & 6 & Discussion (Discussing topics) & 2 \\
\hline Thinking & 5 & Analyzing & 2 \\
\hline Doing research & 5 & Understanding & 2 \\
\hline (Doing experiment) & & Walking & 2 \\
\hline Lectures & 4 & Rules (Regulations) & 2 \\
\hline
\end{tabular}


APPENDIX A (Continued)

\begin{tabular}{lllr}
\hline Learning & 4 & Reading textbooks & 2 \\
Listening & 4 & Swimming & 2 \\
Clubs & 4 & Instances listed once & 36 \\
& & A SPORT & 4 \\
Football & 21 & Volleyball & 4 \\
Baseball & 18 & Badminton & 4 \\
Swimming & 18 & Softball & 3 \\
Tennis & 16 & Jogging & 3 \\
Basketball & 15 & Wrestling & 3 \\
Hockey & 15 & Ice-skating & 3 \\
Soccer & 15 & Bowling & 3 \\
Boxing & 10 & Waterskiing & 3 \\
Handball & 8 & Boating & 3 \\
Golf & 8 & Karate & 3 \\
Raquetball & 7 & Gymnastics & 2 \\
Ping-Pong (Table tennis) & 7 & Roller-skating & 2 \\
Horseback riding & 7 & Hunting & 2 \\
Running & 7 & Sailing & 2 \\
Paddleball & 6 & Squash & 2 \\
Cycling (Bicycle riding) & 6 & Cricket & 2 \\
Skiing & 6 & Polo & 2 \\
Fishing & 5 & Throwing & 2 \\
Horse racing & 5 & Jumping & 2 \\
Car racing & 4 & Getting tired & 40 \\
& & Instances listed once
\end{tabular}

Bath (Bathing, Taking a bath)

\section{A TYPE OF HYGIENIC ACTIVITY}

Brushing teeth

18 Shaving 6

17 Washing face (Cleaning face) 6

(Brushing your teeth)

Shower (Showering,

Taking a shower)

Washing hair (Washing your hair, Shampooing your hair)

Washing hands (Cleaning hands)

Cutting nails Combing (Combing Brushing hair

11 Cleaning ears (Cleaning your ears)

8 Washing Soaping

6 Instances listed once

\section{A TYPE OF SHOPPING}

Clothes shopping (Shopping for clothes)

Food shopping (Shopping for food)

Cars (For car, Automobile)

Grocery shopping (Shopping for groceries)

Sports equipment

(Athletic gear shopping)

Window shopping

Shoes shopping (Shoes)

Looking for house

(For house)

Comparison (Shopping around for best price)

17

17

11

9

7

6

5

5

4

\section{A CRIME}

Rape

Murder

Robbery (Theft)

Stealing (Steal,

Steal something)

Mugging
Furniture shopping

Shopping at supermarket

(Go to supermarket)

Houseware shopping

(Household implements)

Shop for hardware

For bicycle

Toy shopping

Business

Jewelry

Books

Drugs (Drugs \& cosmetics)

Christmas

Instances listed once

Manslaughter

Homicide

Larceny

Trespassing

Child abuse

Kidnapping 
APPENDIX A (Continued)

\begin{tabular}{|c|c|c|c|}
\hline Assault & 8 & Hijacking & 2 \\
\hline Arson & 6 & Libel & 2 \\
\hline Shoplifting & 6 & Purgery & 2 \\
\hline Burglary & 5 & Bigamy & 2 \\
\hline Embezzlement & 4 & Felony & 2 \\
\hline Bribery & 3 & Cheating & 2 \\
\hline Stabbing (Knifing) & 3 & Instances listed once & 58 \\
\hline Killing & 2 & & \\
\hline \multicolumn{4}{|c|}{ A TYPE OF TRANSPORTATION } \\
\hline Bus (Taking a bus, By bus) & 25 & Helicopter & 7 \\
\hline Car (Automobile, & 24 & Horse (Horseback) & 5 \\
\hline Motorcar, By car) & & Running & 4 \\
\hline Train (Taking a train, & 23 & Rocket (Rocketship) & 4 \\
\hline By train) & & Ship & 3 \\
\hline Plane (Airplane, By plane) & 23 & Roller-skates & 3 \\
\hline Bicycle (Bike, By bicycle, & 20 & (Roller-skating) & \\
\hline Bicycle riding, Biking, & & Truck & 2 \\
\hline Riding bike) & & Taxi (Taxicab) & 2 \\
\hline Motorcycle (Motorbike, & 16 & Balloon (Ballooning) & 2 \\
\hline By motorcycle) & & Horse \& buggy & 2 \\
\hline Boat (By boat) & 11 & Jet & 2 \\
\hline Walking & 9 & Ferry & 2 \\
\hline & & Subway & 2 \\
\hline & & Move (Moving) & 2 \\
\hline & & Instances listed once & 29 \\
\hline \multicolumn{4}{|c|}{ A TYPE OF HOUSEWORK } \\
\hline Laundry (Doing laundry, & 18 & Making beds & 7 \\
\hline Washing clothes, & & Cleaning mirrors & 5 \\
\hline Doing the wash) & & Taking out garbage & 4 \\
\hline Dusting & 15 & (Throwing out garbage) & \\
\hline Cooking (Cook) & 15 & Painting & 3 \\
\hline Sweeping (Sweep) & 13 & Cleaning floors & 3 \\
\hline Vacuuming (Vacuum, & 12 & Ironing & 2 \\
\hline Hoovering) & & Sweeping the floor & 2 \\
\hline Washing dishes & 11 & Dusting furniture & 2 \\
\hline (Doing dishes, Dishes) & & Waxing floors & 2 \\
\hline Clean windows & 11 & Waxing & 2 \\
\hline (Washing windows) & & Cleaning the bathtub & 2 \\
\hline Mopping & 9 & Shopping & 2 \\
\hline (Mopping floors) & & Baking (Bake) & 2 \\
\hline & & Instances listed once & 32 \\
\hline
\end{tabular}

Note-27 subjects generated instances for each superordinate.

\section{APPENDIX B}

Superordinate Categories and Subordinate Instances Listed for Basic Categories*

\begin{tabular}{|c|c|c|c|c|c|c|c|}
\hline Superordinates & Freq. & Subordinates & Freq. & Superordinates & Freq. & Subordinates & Freq \\
\hline \multicolumn{8}{|c|}{ MEALS } \\
\hline \multicolumn{4}{|c|}{ Breakfast } & \multicolumn{4}{|c|}{ Snack } \\
\hline Meal (Mealtime) & 8 & Bacon \& eggs & 3 & Meal & 3 & \multirow{2}{*}{$\begin{array}{l}\text { Chips (Potato } \\
\text { chips) }\end{array}$} & 5 \\
\hline Eating activity & 3 & Eggs, juice \& & 2 & Eating & 2 & & \\
\hline Nourishment & 2 & toast & & Food (Food & 2 & Cookies & 3 \\
\hline (Nutrition) & & Quick breakfast & 2 & consumption) & & Candies & 2 \\
\hline Superordinates & 4 & Cereal \& milk & 2 & Enjoyable activity & 2 & Pretzels & 2 \\
\hline listed once & & Going out for & 2 & (Enjoyment) & & In-between-meals & 2 \\
\hline & & $\begin{array}{l}\text { pancakes } \\
\text { Brunch }\end{array}$ & 2 & $\begin{array}{l}\text { Superordinates } \\
\text { listed once }\end{array}$ & 5 & $\begin{array}{l}\text { snack (Tide- } \\
\text { over snack) }\end{array}$ & \\
\hline
\end{tabular}


APPENDIX B (Continued)




APPENDIX B (Continued)

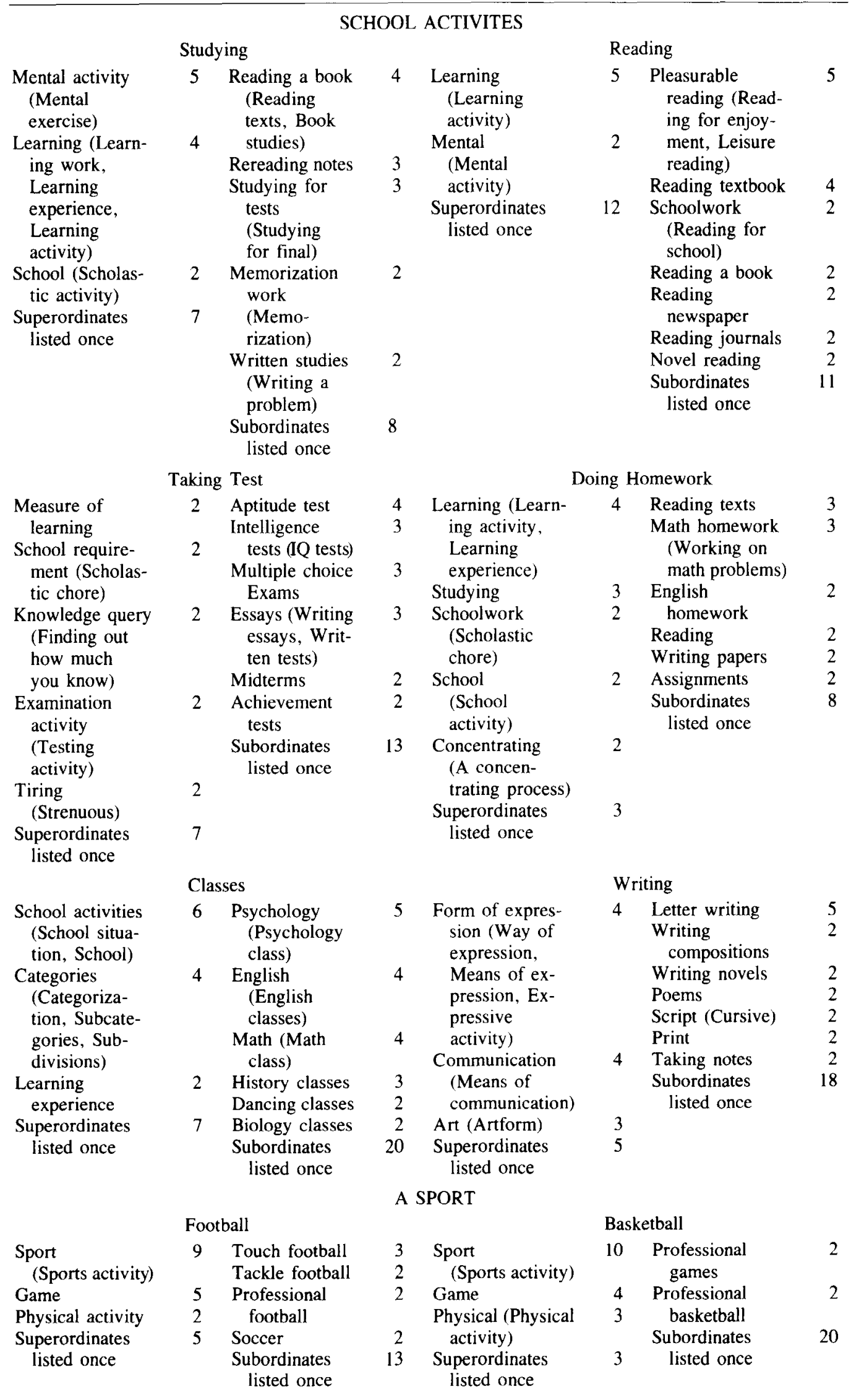


APPENDIX B (Continued)

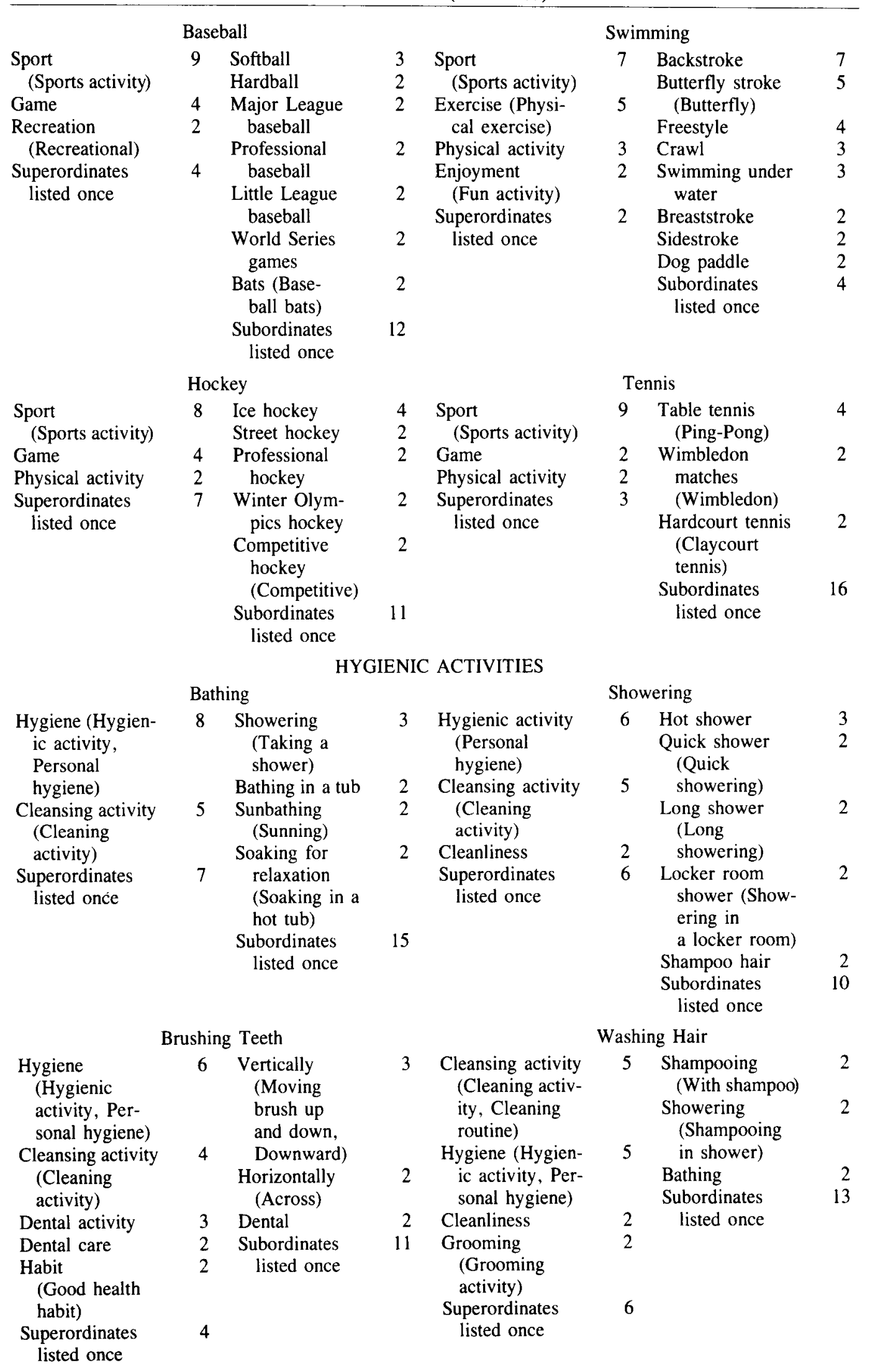


APPENDIX B (Continued)

\begin{tabular}{|c|c|c|c|c|c|c|c|}
\hline \multicolumn{4}{|c|}{ Washing Hands } & \multicolumn{4}{|c|}{ Cutting Nails } \\
\hline \multirow{11}{*}{$\begin{array}{l}\text { Hygiene } \\
\text { (Hygienic } \\
\text { activity, Per- } \\
\text { sonal hygiene) } \\
\text { Cleaning activity } \\
\text { (Cleansing } \\
\text { activity) } \\
\text { Grooming } \\
\text { Superordinates } \\
\text { listed once }\end{array}$} & 8 & $\begin{array}{l}\text { Washing with } \\
\text { soap \& water }\end{array}$ & 3 & $\begin{array}{l}\text { Grooming (Per- } \\
\text { sonal grooming) }\end{array}$ & 6 & $\begin{array}{l}\text { Filing } \\
\quad \text { (Filing nails) }\end{array}$ & 3 \\
\hline & & (Using soap & & Hygienic (Per- & 5 & Manicure & 2 \\
\hline & & $\&$ water) & & sonal hygiene, & & Trimming & 2 \\
\hline & 5 & $\begin{array}{l}\text { Lathering } \\
\text { hands }\end{array}$ & 2 & $\begin{array}{l}\text { Hygienic } \\
\text { activity) }\end{array}$ & & $\begin{array}{l}\text { (Trimming } \\
\text { nails) }\end{array}$ & \\
\hline & & Washing hands & 2 & Superordinates & 4 & Shortening & 2 \\
\hline & 2 & quickly & & listed once & & Using Clippers & 2 \\
\hline & 5 & Rinsing hands & 2 & & & (With a nail- & \\
\hline & & Rinsing hands & 2 & & & clipper) & \\
\hline & & $\begin{array}{l}\text { in a river } \\
\text { (Rinsing in a } \\
\text { stream or } \\
\text { creek) }\end{array}$ & & & & $\begin{array}{l}\text { Subordinates } \\
\text { listed once }\end{array}$ & 7 \\
\hline & & $\begin{array}{l}\text { Subordinates } \\
\text { listed once }\end{array}$ & 11 & & & & \\
\hline & & & SH & PING & & & \\
\hline \multicolumn{3}{|c|}{ Clothes Shopping } & & \multicolumn{4}{|c|}{ Shopping for Car } \\
\hline \multirow{2}{*}{$\begin{array}{l}\text { Shopping activity } \\
\text { (Necessary } \\
\text { shopping) } \\
\text { Necessary activi- } \\
\text { ty (Necessary) }\end{array}$} & 3 & $\begin{array}{l}\text { Buying Shoes } \\
\text { (Buying a } \\
\text { pair of shoes) }\end{array}$ & 2 & \multirow{3}{*}{$\begin{array}{l}\text { Shopping } \\
\text { Providing } \\
\text { transportation } \\
\text { (Acquiring a } \\
\text { form of } \\
\text { transportation) }\end{array}$} & $\begin{array}{l}2 \\
2\end{array}$ & \multirow{2}{*}{$\begin{array}{l}\text { Shopping for a } \\
\text { sports car } \\
\text { Going to a used- } \\
\text { car lot }\end{array}$} & $\begin{array}{l}2 \\
2\end{array}$ \\
\hline & 2 & $\begin{array}{l}\text { Shopping for } \\
\text { shirts (Buying }\end{array}$ & 2 & & & & 11 \\
\hline Leisure activity & 2 & a new shirt) & & & & listed once & \\
\hline $\begin{array}{l}\text { Money } \\
\text { (Using money) }\end{array}$ & 2 & $\begin{array}{l}\text { Shopping for } \\
\text { pants (Buying }\end{array}$ & 2 & $\begin{array}{l}\text { Superordinates } \\
\text { listed once }\end{array}$ & 7 & & \\
\hline $\begin{array}{l}\text { Selecting } \\
\quad \text { (Choosing) }\end{array}$ & 2 & $\begin{array}{l}\text { pants or } \\
\text { skirts) }\end{array}$ & & & & & \\
\hline $\begin{array}{l}\text { Superordinates } \\
\text { listed once }\end{array}$ & 5 & $\begin{array}{l}\text { Subordinates } \\
\text { listed once }\end{array}$ & 13 & & & & \\
\hline \multicolumn{3}{|c|}{ Food Shopping } & & \multicolumn{4}{|c|}{ Shopping for Sports Equipment } \\
\hline \multirow{6}{*}{$\begin{array}{l}\text { Shopping (Shop- } \\
\text { ping activity, } \\
\text { Necessary } \\
\text { shopping } \\
\text { activity) } \\
\text { Domestic activity } \\
\text { (Household } \\
\text { activity) } \\
\text { Necessity (Essen- } \\
\text { tial activity) }\end{array}$} & 4 & $\begin{array}{l}\text { Buying meat } \\
\text { (Buying meat } \\
\text { products, } \\
\text { Meat }\end{array}$ & 6 & \multirow{9}{*}{$\begin{array}{l}\text { Shopping activity } \\
\text { Leisure activity } \\
\text { (Free-time } \\
\text { activity) } \\
\text { Superordinates } \\
\text { listed once }\end{array}$} & $\begin{array}{l}3 \\
2\end{array}$ & $\begin{array}{l}\text { Outfitting a team } \\
\text { (Buying uni- } \\
\text { forms for } \\
\text { a team) }\end{array}$ & 3 \\
\hline & & shopping) & & & 7 & Shopping for & 2 \\
\hline & 2 & $\begin{array}{l}\text { Fruit shopping } \\
\text { (Buying fruit) }\end{array}$ & 4 & & & $\begin{array}{l}\text { basketball } \\
\text { Shopping for }\end{array}$ & 2 \\
\hline & & Going to & 2 & & & tennis racket & \\
\hline & 2 & butcher & & & & Buying a baseball & 2 \\
\hline & & Buying & 2 & & & bat $\&$ glove & \\
\hline \multirow{3}{*}{$\begin{array}{l}\text { Superordinates } \\
\text { listed once }\end{array}$} & 7 & vegetables & & & & Subordinates & 14 \\
\hline & & Buying milk & 2 & & & listed once & \\
\hline & & $\begin{array}{l}\text { Subordinates } \\
\text { listed once }\end{array}$ & 10 & & & & \\
\hline \multicolumn{3}{|c|}{ Grocery Shopping } & & \multicolumn{4}{|c|}{ Furniture Shopping } \\
\hline \multirow{5}{*}{$\begin{array}{l}\text { Shopping activity } \\
\text { (Necessary } \\
\text { shopping } \\
\text { activity) } \\
\text { Domestic activi- } \\
\text { ty (Household } \\
\text { chore, Caring } \\
\text { of home) } \\
\text { Superordinates } \\
\text { listed once }\end{array}$} & 3 & $\begin{array}{l}\text { Going to meat } \\
\text { market (Buy- } \\
\text { ing meat at } \\
\text { the butcher) }\end{array}$ & 3 & \multirow{5}{*}{$\begin{array}{l}\text { Shopping activity } \\
\text { Decorative activ- } \\
\text { ity (Decorating } \\
\text { activity) } \\
\text { Purchasing (Buy- } \\
\text { ing or pur- } \\
\text { chasing) } \\
\text { Furnishing an } \\
\text { apartment (Get- } \\
\text { ting things to } \\
\text { furnish an } \\
\text { apartment) }\end{array}$} & $\begin{array}{l}3 \\
2\end{array}$ & $\begin{array}{l}\text { Shopping for } \\
\text { bedroom } \\
\text { furniture } \\
\text { Buying a dining }\end{array}$ & 2 \\
\hline & 3 & $\begin{array}{l}\text { Buying meat, } \\
\text { milk, etc. } \\
\text { Going to buy }\end{array}$ & 2 & & 2 & $\begin{array}{l}\text { room set } \\
\text { (Buying a new } \\
\text { dining room set) }\end{array}$ & \\
\hline & & milk & & & 2 & Table (Looking & 2 \\
\hline & 9 & $\begin{array}{l}\text { Going to buy } \\
\text { eggs }\end{array}$ & 2 & & & $\begin{array}{l}\text { or shopping } \\
\text { for a table) }\end{array}$ & \\
\hline & & $\begin{array}{l}\text { Shopping for } \\
\text { fruit }\end{array}$ & 2 & & & $\begin{array}{l}\text { Chair (Looking } \\
\text { or shopping for }\end{array}$ & 2 \\
\hline
\end{tabular}


APPENDIX B (Continued)

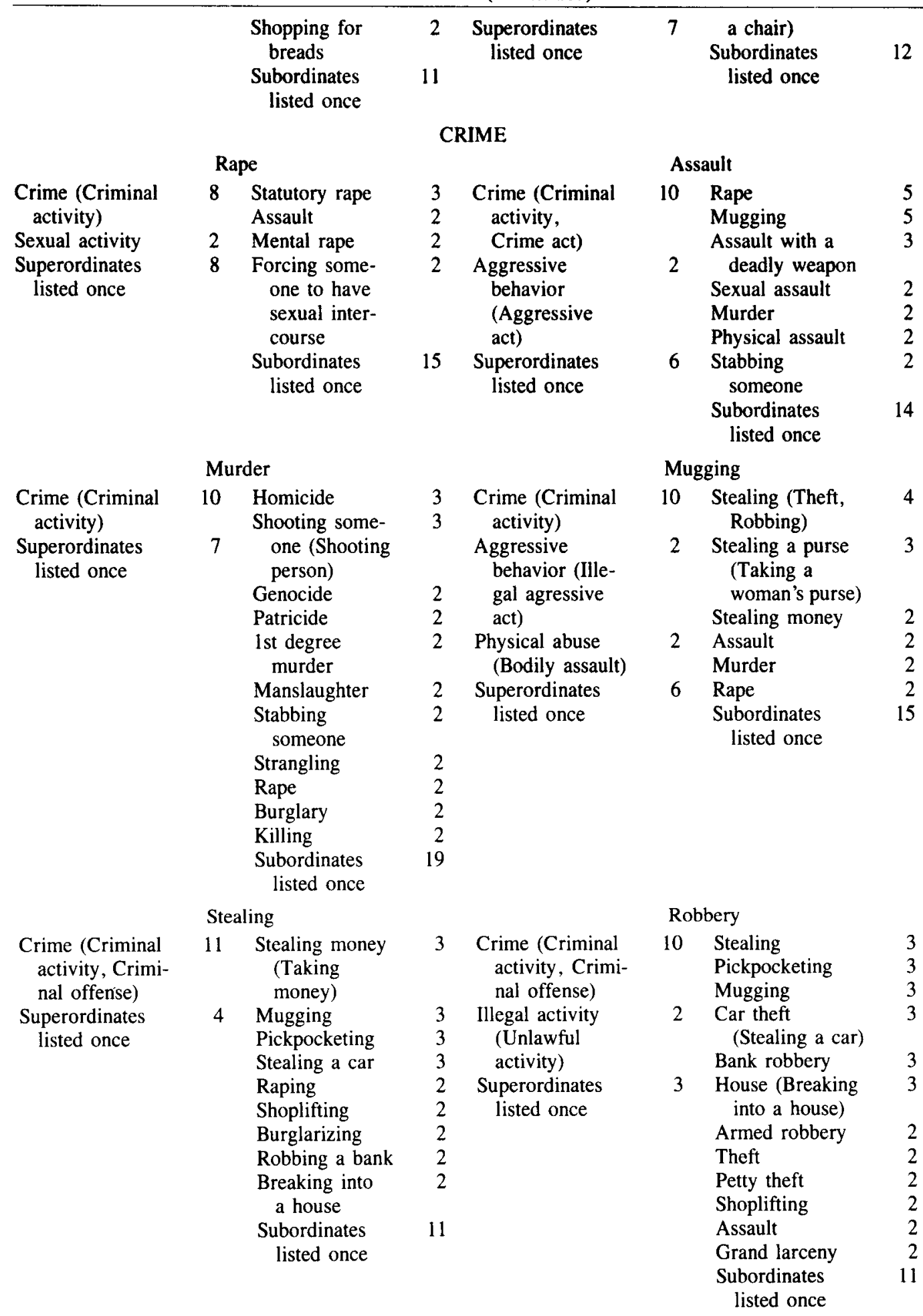

\section{TRANSPORTATION}

Traveling by Bus

$\begin{array}{lc}\begin{array}{l}\text { Transportation } \\ \text { (Transportation }\end{array} & \begin{array}{c}\text { Traveling to } \\ \text { school (Tak- } \\ \text { activity, Way }\end{array} \\ \begin{array}{l}\text { ing a bus } \\ \text { to get to desti- } \\ \text { nation, Way to }\end{array} & \text { to school) }\end{array}$

Traveling by Plane
3 Type of travel (Travel activity, Way to get to destination)
2 Vacation activity

\section{2}

5
3
2
2
4
2
2
2
2


APPENDIX B (Continued)

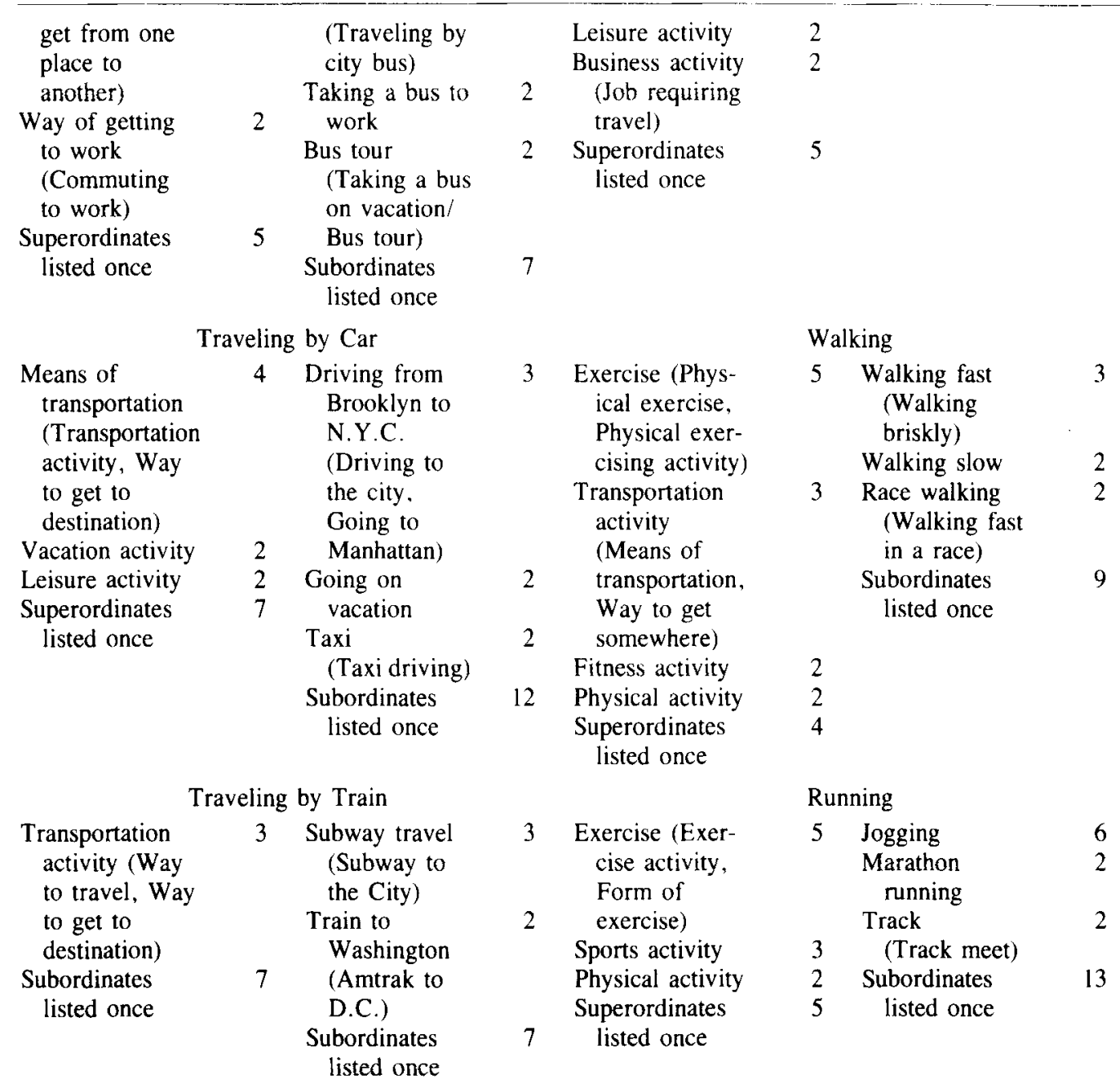

\section{HOUSEWORK}

Cleaning
(Cleaning activ-
ity)
Doing housework
(Household
chore)
Superordinates
listed once

Laundry

3 Chinese laundry

Dry clean

(Cleaners)

2 Colored wash (Dark)

White wash

7 (Light)

Subordinates

listed once

Dusting

$\begin{array}{lcc}\begin{array}{c}\text { Cleaning } \\ \text { (Cleaning ac- } \\ \text { tivity, Cleaning }\end{array} & 6 & \begin{array}{c}\text { Dusting cloth } \\ \text { (Rag) } \\ \text { method) }\end{array} \\ \begin{array}{l}\text { Dousting under } \\ \text { bed (Cleaning }\end{array} \\ \begin{array}{l}\text { Superordinates } \\ \text { listed once }\end{array} & 3 & \begin{array}{c}\text { under bed) } \\ \text { Featherdusting } \\ \text { (Wiping fur- } \\ \text { niture with a } \\ \text { featherduster) }\end{array}\end{array}$

\section{Sweeping}

4 Sweeping floor 3

Sweeping dirt 2

(Cleaning action)

2 Housework (Household chore)

Superordinates

16 listed once

2 Sweeping rug 2

(Sweeping carpet)

6 Vacuuming

(Using an

electric broom)

Subordinates

listed once

Vacuuming

3 Cleaning activity

5 Vacuuming rugs

(Rug)

(Cleaning

action)

Housework

(Household

chore)

Superordinates

listed once

Vacuuming car- 3

2 pet (Vacuuming carpet in your house)

6 Vacuuming car (Vacuuming your car) 
APPENDIX B (Continued)

\begin{tabular}{|c|c|c|c|c|c|c|c|}
\hline & & $\begin{array}{l}\text { Dust furniture } \\
\text { (Wipe furni- } \\
\text { ture) } \\
\text { Dust room } \\
\text { (Clean room) } \\
\text { Subordinates } \\
\text { listed once }\end{array}$ & $\begin{array}{r}2 \\
12\end{array}$ & & & $\begin{array}{l}\text { Vacuuming } \\
\text { drapes } \\
\text { Dusting } \\
\text { Vacuum cleaner } \\
\text { Subordinates } \\
\text { listed once }\end{array}$ & $\begin{array}{r}2 \\
2 \\
10\end{array}$ \\
\hline \multicolumn{4}{|c|}{ Cooking } & \multicolumn{4}{|c|}{ Washing Dishes } \\
\hline $\begin{array}{l}\text { Act of preparing } \\
\text { meal (Eating } \\
\text { preparations) }\end{array}$ & 2 & $\begin{array}{l}\text { Frying } \\
\text { Boiling } \\
\text { Baking a cake }\end{array}$ & $\begin{array}{l}2 \\
2 \\
2\end{array}$ & $\begin{array}{l}\text { Cleaning activity } \\
\text { (Cleanliness } \\
\text { activity) }\end{array}$ & 4 & $\begin{array}{l}\text { Dishwasher } \\
\text { (Loading } \\
\text { dishwasher) }\end{array}$ & 3 \\
\hline $\begin{array}{l}\text { Enjoyable activi- } \\
\text { ty (Enjoyment) }\end{array}$ & 2 & $\begin{array}{l}\text { (Making a } \\
\text { cake) }\end{array}$ & & $\begin{array}{l}\text { Household chore } \\
\text { (Housework) }\end{array}$ & 3 & $\begin{array}{l}\text { Washing pans } \\
\text { (Scrubbing pots }\end{array}$ & 3 \\
\hline \multirow[t]{2}{*}{$\begin{array}{l}\text { Superordinates } \\
\text { listed once }\end{array}$} & 7 & $\begin{array}{l}\text { Cooking for } \\
\text { family } \\
\text { Subordinates } \\
\text { listed once }\end{array}$ & $\begin{array}{r}2 \\
21\end{array}$ & $\begin{array}{l}\text { Superordinates } \\
\text { listed once }\end{array}$ & 5 & $\begin{array}{l}\& \text { pans) } \\
\text { Washing dinner } \\
\text { dishes (Dinner } \\
\text { dishes) }\end{array}$ & 2 \\
\hline & & & & & & $\begin{array}{l}\text { Subordinates } \\
\text { listed once }\end{array}$ & 12 \\
\hline
\end{tabular}

Note-12 subjects generated responses for each basic category.

APPENDIX C

Final Tally of Attributes for Each Item in the Nine Taxonomies*

\begin{tabular}{rccccc}
\hline Superordinate & Freq. & Basic Level & Freq. & Subordinate & Freq. \\
Meal & & Breakfast & & Quick Breakfast &
\end{tabular}

Food (o)

Table (o)

Family (p)

Enjoyment (ps)

Dinner (bas)

Breakfast (bas)

Features listed twice

Features listed once

Tax. terms listed twice

Tax. terms listed once
Toast (o)

Coffee (o)

Eggs (o)

Juice (o)

Milk (o)

Bacon (o)

Pancakes (o)

Orange juice (o)

Diner (1)

Early $(t)$

Morning ( $\mathrm{t}$ )

Features listed twice

Features listed once

Tax. terms listed twice

Tax. terms listed once

Dinner

Meat (o)

Vegetables (o)

Food (o)

Restaurant (1)

Family (p)

Eating (a)

Drink (a)

Cooking (a)

Features listed twice

Features listed once

Tax. terms listed twice

Tax. terms listed once

Entertainment

Friends ( $p$ )

Movies (bas)
The Movies

5 Popcorn (o)

8 Seats (o)
Milk (o)

5

Cereal (o)

Coffee (o)

Juice (o)

Toast (o)

Late $(\mathrm{t})$

Features listed twice

Features listed once

Tax. terms listed twice

Tax. terms listed once

Family Dinner

Food (o)

Knives (o)

Forks (o)

Glasses (o)

Table (o)

Sister (p)

Mother (p)

Brother (p)

Conversation (a)

Washing dishes (a)

Features listed twice

Features listed once

Tax. terms listed twice

Tax. terms listed once

Horror Movie

Blood (o)

People (p)
3

3

3

3

5

3

3

3

3

9

39

2

1 
APPENDIX C (Continued)

\begin{tabular}{lrlrlr}
\hline TV (bas) & 6 & Screen (o) & 4 & Screaming (a) & 5 \\
Parties (bas) & 4 & Film (o) & 3 & Scared (ps) & 3 \\
Dancing (bas) & 3 & Tickets (o) & 3 & Features listed twice & 9 \\
Concerts (bas) & 3 & Actors (p) & 4 & Features listed once & 53 \\
Features listed twice & 3 & Entertainment (super) & 3 & Tax. terms listed twice & 0 \\
Features listed once & 31 & Mysteries (sub) & 3 & Tax. terms listed once & 0 \\
Tax. terms listed twice & 7 & Features listed twice & 10 & \\
Tax. terms listed once & 11 & Features listed once & 64 & \\
& & Tax. terms listed twice & 2 & \\
& & Tax. terms listed once & 5 &
\end{tabular}

\section{Theatre}

Tickets (o)

Expensive (ab)

Actors (p)

Audience ( $p$ )

Applause (a)

Broadway (sub)

Movies (sub)

Drama (sub)

Comedy (sub)

Musical (sub)

Features listed twice

Features listed once

Tax. terms listed twice

Tax. terms listed once

School Activities

Friends (p)

Studying (bas)

Football games (bas)

Features listed twice

Features listed once

Tax. terms listed twice

Tax. terms listed once

\section{Classes}

Books (o)

Desks (o)

Teacher (p)

Tests (a)

Writing (a)

Taking notes (a)

Homework (a)
Features listed twice

Features listed once

Tax. terms listed twice

Tax. terms listed once

\section{Tests}

Grades (ou)

Passing (ou)

Failing (ou)

Studying (a)

Nervous (ps)

Essays (sub)

Multiple choice (sub)

Features listed twice

Features listed once

Tax. terms listed twice

Tax. terms listed once

Football

Exercise (a)

Competition (ps)

Fun (ps)

Baseball (bas)

Football (bas)

Tennis (bas)

Basketball (bas)

Swimming (bas)

Features listed twice

\section{all (o)}

Helmets (o)

Cold (pa)

Stadiums (1)

Field (1)

Touchdowns (ou)

Cheerleaders (p)

Players (p)

Big men (p)
Comedy at the Theatre

Costumes (o)

Lights (o)

Scenery (o)

Tickets (o)

Stage (1)

Actors (p)

Audience (p)

Actresses (p)

Laughing (a)

Jokes (a)

Enjoyment (ps)

Features listed twice

Features listed once

Tax. terms listed twice

Tax. terms listed once

English Class

Books (o)

Pen (o)

Grammar (ab)

Teacher (p)

Reading (a)

Writing (a)

Boring (ps)

Features listed twice

Features listed once

Tax. terms listed twice

Tax. terms listed once

Essay Tests

Pen (o)

Paper (o)

Writing (a)

Nervous (ps)

Features listed twice

Features listed once

Tax. terms listed twice

Tax. terms listed once

Touch Football

Football (o)

Running (a)

Falling (a)

Features listed twice

Features listed once

Tax. terms listed twice

Tax. terms listed once

\section{5}

0

0


Features listed once

Tax. terms listed twice

Tax. terms listed once

Hygiene

Soap (o)

Clean (a)

Cleanliness (ps)

Shower (bas)

Features listed twice

Features listed once

Tax. terms listed twice

Tax. terms listed once

\section{Shopping}

\section{Money (o)}

Fun (ps)

Clothes (bas)

Features listed twice

Features listed once

Tax. terms listed twice

Tax. terms listed once
Features listed twice

Features listed once

Tax. terms listed twice

Tax. terms listed once

$$
\text { Hockey }
$$

Ice (o)

Sticks (o)

Puck (o)

Skates (o)

Madison Square

Garden (1)

Goals (ou)

Score (ou)

Players (p)

Goalie (p)

NY Islanders (p)

Skating (a)

Features listed twice

Features listed once

Tax. terms listed twice

Tax. terms listed once

\section{Washing Hands}

Soap (o)

Towel (o)

Sink (o)

Water (o)

Dirty (pa)

Bathroom (1)

Clean (a)

Features listed twice

Features listed once

Tax. terms listed twice

Tax. terms listed once

Shower

Soap (o)

Water (o)

Towel (o)

Wet (pa)

Hot (pa)

Bathroom (1)

Clean (a)

Refreshing (ps)

Features listed twice

Features listed once

Tax. terms listed twice

Tax. terms listed once

Food Shopping

Shopping cart (o)

Coupons (o)

Money (o)

Food (o)

Cash register (o)

Fruit (o)

Groceries (o)

Cars (o)

Supermarket (1)

People (p)

Lines (p)

Features listed twice
11

52

6

Professional Hockey

Ice (o)

Uniforms (o)

Ice skates (o)

Hockey sticks (o)

Sticks (o)

Puck (o)

Net (o)

Madison Square

Garden (1)

NY Rangers (p)

Fans (p)

Players (p)

Fighting (a)

Features listed twice 8

Features listed once $\quad 42$

Tax. terms listed twice

Tax. terms listed once

Washing Hands Quickly

Water (o)

Cold water (o)

Towel (o)

Rush (ps)

Features listed twice 7

Features listed once $\quad 41$

Tax. terms listed twice 0

Tax. terms listed once

Locker Room Shower

Soap (o)

Towels (o)

Water (o)

Clothes (o)

Gym (1)

Features listed twice $\quad 10$

Features listed once $\quad 40$

Tax. terms listed twice 0

Tax. terms listed once

Shopping at Butcher Shop

Meat (o)

Blood (o)

Scales (o)

Sawdust (o)

Knife (o)

High prices (ab)

Butcher (p)

Features listed twice 5

Features listed once $\quad 40$

Tax. terms listed twice 0

Tax. terms listed once 0 


Features listed once
Tax. terms listed twice
Tax. terms listed once
Furniture Shopping
Colors (pa)
Features listed twice
Features listed once
Tax. terms listed twice
Tax. terms listed once

Crime

N.Y.C. (1)

Stealing (bas)

Drugs (bas)

Raping (bas)

Mugging (bas)

Features listed twice

Features listed once

Tax. terms listed twice

Tax. terms listed once

Transportation

No attributes

Car (bas)

Train (bas)

Bus (bas)

Airplane (bas)

Subway (bas)

Features listed twice

Features listed once

Tax. terms listed twice

Tax. terms listed once

Features listed once

Tax. terms listed twice

Tax. terms listed once

Assault

Subway (1)

Battery (a)

Mugging (sub)

Features listed twice

Features listed once

Tax. terms listed twice

Tax. terms listed once

\section{Train Travel}

Tokens (o)

Seats (o)

Books (o)

Noisy (pa)

Dirty (pa)

People (p)

Features listed twice

Features listed once

Tax. terms listed twice

Tax. terms listed once
43

1

1

Shopping for Bedroom Furniture

Bed (o)

Lamps (o)

Expensive (ab) 3

Features listed twice 8

$10 \quad$ Features listed once 45

Tax. terms listed twice 0

Tax. terms listed once 1

Homicide

Gun (o) 4

Knife (o) 3

Blood (o) 3

Morgue (1) 3

Police (p) 6

Victim (p) 3

Detectives (p) 3

Murder (bas) 3

Features listed twice 4

Features listed once $\quad 39$

Tax. terms listed twice 0

Tax. terms listed once 4

Bus Travel

Sleeping (a)

Features listed twice

Features listed once

Tax. terms listed twice

Tax. terms listed once
Assault with a Deadly Weapon

Gun (o)

Knife (o)

Blood (o)

Jail (1)

Police (p)

Victim (p)

Features listed twice

Features listed once 38

Tax. terms listed twice 2

Tax. terms listed once 5

Subway Travel

Tokens (o) 3

Seat (o) 3

Graffiti (o) 3

Cars (o) 4

Hot (pa) 5

Dirty (pa) 5

Noise (pa) 3

Crowded (pa) 3

Conductor (p) 3

Pushing (a) 3

Features listed twice 9

Features listed once $\quad 55$

Tax. terms listed twice 0

Tax. terms listed once 3

Traveling by City Bus

Hot (pa)

Crowded (pa)

Expensive (ab)

Late $(\mathrm{t})$

Bus driver ( $p$ )

Features listed twice



8

6

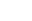

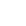

(2)


Housework

Cleaning (a)

Washing (a)

Dusting (bas)

Ironing (bas)

Dishes (bas)

Features listed twice

Features listed once

Tax. terms listed twice

Tax. terms listed once
Vacuuming

Carpet (o)

Rug (o)

Dirt (o)

Dust (o)

Machine (o)

Noise (pa)

Cleaning (a)

Features listed twice

Features listed once

Tax. terms listed twice

Tax. terms listed once

Sweeping

Broom (o)

Dirt (o)

Dustpan (o)

Dust (o)

Features listed twice

Features listed once

Tax. terms listed twice

Tax. terms listed once
Features listed once

44

Tax. terms listed twice

Tax. terms listed once

0

2

Vacuuming Carpet

Dirt (o)

Noise (pa)

Moving furniture (a)

Changing bag (a)

Features listed twice

Features listed once

Tax. terms listed twice

Tax. terms listed once

\section{Sweeping Floor}

Broom (o)

Dustpan (o)

Dirt (o)

Dust (o)

Mop (o)

Floor (1)

Features listed twic

Features listed once

Tax. terms listed twice 0

Tax. terms listed once
5

4

4

3

6

30

0

0

Note-10 subjects generated responses for each category. Attribute types are shown as follows: $o=$ objects, pa $=$ physical attributes, $l=$ locations, ou = outcomes, $a b=$ abstract,$t=$ time, $p=$ persons, $a=$ actions, $p s=$ personal states. Taxonomic terms are as follows: super $=$ superordinates, bas $=$ basic, and sub $=$ subordinates.

(Manuscript received December 28, 1984;

revision accepted for publication November 8,1985 .) 